\title{
DAMNED IF YOU DO, DAMNED IF YOU DON'T: RELIGIOUS SHUNNING AND THE FREE EXERGISE GLAUSE
}

\author{
JUSTIN K. MILLER $\dagger$
}

Throughout history, families and religious groups have recognized their influence over the lives of their members and have used this influence to maintain unity and adherence to a given set of values. ${ }^{1}$ The scenario in which the head of the family threatens to disown the prodigal child is familiar because it strikes an elemental chord: the fear that parental love will be withdrawn, casting the child adrift in the world with no identity and no roots. ${ }^{2}$ The myth has ancient origins: in the Bible, Adam and Eve were thrown out of the Garden of Eden for disobeying God's command. ${ }^{3}$

Today, many religious groups consider themselves to be God's "chosen" people, frequently to the exclusion of others." When religious groups believe that they are the "chosen," they may treat former members in a way that is intended to cause them hardship. This may occur whether the group expels or excommunicates a member against her

† B.A. 1983, University of Pennsylvania; J.D. Candidate 1989, University of Pennsylvania.

1 For example, some small Jewish communities keep a "bluebook" in which the names of community members, along with the amount they have donated to charities, are published to reinforce commonly held values of generosity and charity. See B. Raven \& J. Rubin, Social Psychology: People in Groups 338 (1976).

${ }^{2}$ Cf. id. at 43-45 (anxiety tends to make people desire affiliation with others) (quoting E. BerscheID \& E. WALSTER, INTERPERSONAL ATTRACTION 32 (1969)); S. Schachter, The Psychology of Affiliation 13-14 (1959).

S See Genesis 3:23-24 (Oxford Annotated Bible rev. standard version) ("TT]herefore the LORD God sent him forth from the garden of Eden, to till the ground from which he was taken. He drove out the man; and at the east of the garden of Eden he placed the cherubim, and a flaming sword which turned every way, to guard the way to the tree of life." (verse citation omitted)). The rest of biblical history can be interpreted as a consequence of Adam's sin. See The ReAder's BIBLE: A NarRative xix-xx (R. Frye ed. 1965); see also The WrItIngs of MARTIN BubER 28 (W. Herberg ed. 1956) ("We each reenact Adam's 'fall,' which 'continually happens here and now in all its reality." (quoting Buber, The Faith of Judaism, in ISRAEL AND THE WORLD: EsSAYS IN A TIME OF CRISIS 17 (1948))).

4 This has been a recurrent phenomenon historically. See M. Ben-Horin, Common FaIth-Uncommon People: Essays in Reconstructionist Judaism 26 (noting the doctrine of "choseness" in the Jewish religion); 5 THE ENCYCLOPEDIA OF REIIGION 75 (M. Eliade ed. 1987) (discussing the doctrine of election in Christianity, Judaism, and Islam); The Reader's BIBLE, supra note 3, at xxi (describing the race of Abraham as God's choice for a "laboratory school for the development of a conception of human personality and... society"). 


\section{will or the former member leaves of her own accord.}

This Comment discusses the practice of "shunning," which involves the complete withdrawal of social, spiritual, and economic contact from a member or former member of a religious group. ${ }^{\circ}$ The shunned person can lose, among other things, her spouse, ${ }^{6}$

S A number of religions currently practice this extreme form of shunning. The practice of Bann und Meidung is a moral principle in the Amish community. Translated, the words mean excommunication and shunning.

Meidung requires that members receive no favors from the excommunicated person, that they do not buy from or sell to an excommunicated person, that no member shall eat at the same table with an excommunicated person, and if the case involves husband or wife, they are to suspend their usual marital relations.

J. Hostetler, Amish Society 63 (1963); see also R. Bear, Delivered Unto SATAN 1-4 (1974) (discussing a similar practice in the Reformed Mennonite Church).

Jehovah's Witnesses shun members after a process called "disfellowshipping."

"Members of the Jehovah's Witness community are prohibited-under threat of their own disfellowship-from having any contact with disfellowshipped persons and may not even greet them." Paul v. Watchtower Bible \& Tract Soc'y of N.Y., Inc., 819 F.2d 875, 876 (9th Cir.), cert. denied, 108 S. Ct. 289 (1987); see also J. Bergman, JeHoVAH'S WITNESSES AND KINDRED GROUPS at xxiii (1984) (discussing how dissenting Witnesses, who in 1938 voluntarily left the Society because of doctrinal differences, were "treated with indignation and animosity by their former brothers"). Family members are required to shun other family members who are disfellowshipped. See id. For other examples of religious groups that practice shunning, see Grunwald v. Ben Zion Bornfreund, No. GV-85-3338 (E.D.N.Y. Sept. 20, 1988) (discussing siruv niddui and herem, forms of excommunication in the Orthodox Jewish community); Quiner v. Quiner, 59 Cal. Rptr. 503, 504 (Ct. App. 1967) (discussing the "concept of "separation," which, as practiced by a Christian sect called the Plymouth Brethren, or "Exclusive Brethren," entails minimizing contacts with persons outside the group); In re Marriage of Hadeen, 27 Wash. App. 566, 569, 619 P.2d 374, 376 (1980) (describing the First Community Church's practice of shunning and ostracizing members).

Shunning is not a practice limited to religious groups:

British workers have been known to carry the "silent treatment" to an extreme, as in the case of a worker who is "sent to Coventry." In this form of ostracism, no one will speak to the deviant or his family unless it is absolutely necessary. The effect can be devastating to the point of suicide.

B. RAVEN \& J. RUBIN, supra note 1, at 324-25.

See, e.g., Johnson v. Johnson, 564 P.2d 71, $72-73$ (Alaska 1977), cert. denied 434 U.S. 1048 (1978) (marriage ended in divorce when, after husband was disfellowshipped for smoking cigarettes, wife refused to communicate with him); Quiner, 59 Cal. Rptr. at 504-05 (wife, who belonged to the "Exclusive Brethren," adhered to its doctrine of separation, which prevented her from interacting with her husband); Linderman v. Linderman, 364 N.W.2d 872, 874 (Minn. Ct. App. 1985) (marriage ended in divorce when wife was shunned after leaving church group); Bear v. Reformed Mennonite Church, 462 Pa. 330, 332-33, 341 A.2d 105, 106 (1975) (after husband was excommunicated from church, wife would not speak to him); $c f$. Mohn v. Tingley, 191 Cal. 470, 489, 217 P. 733, 742 (1923) (leader of Theosophical Society caused member to leave his wife); Radecki v. Schuckardt, 50 Ohio App. 2d 92, 92, 361 N.E.2d 543, 544 (1976) (plaintiff alleged that Bishop of Christ the King Priory, Inc., caused his wife, who was a member, to leave him); Bradesku v. Antion, 21 Ohio App. 2d 67, 68-69, 255 N.E.2d 265, 267 (1969) (wife filed for divorce after minister of Radio 
children, ${ }^{7}$ business, ${ }^{8}$ and standing in the community.

Unique legal issues are raised when people who are shunned sue their churches. Shunning frequently causes a collision of state common law, family law, and the free exercise clause of the first amendment. Religious groups shun former members out of the sincere religious conviction that they are doing the right thing, but such conduct intentionally hurts the person who is shunned. Shunning is not evil in itself, but, if groups are given license to shun at will, there is potential for abuse. By definition, shunning seeks to quell dissent and subject individuals to the will of the group. This Comment questions whether the Constitution should elevate the rights of religious groups above the rights of individual members of religious groups. It concludes that absolute constitutional protection for shunning is inappropriate.

This Comment begins by outlining the constitutional protections given to religiously motivated conduct under contemporary interpretations of the first amendment, and it proposes that the standard enunciated in Sherbert $v$. Verner, ${ }^{9}$ which dictates when religious practices should be excepted from facially neutral government regulations, be applied cautiously in shunning cases. The Comment then argues that the

Church of God wrote her a letter stating that her relationship with her husband was adulterous because he had been married previously); Carrieri v. Bush, 69 Wash. 2d 536, 538, 419 P.2d 132, 135 (1966) (church pastor required member's wife to take an oath that she would not listen to her husband and would not leave her church).

7 See Bear, $462 \mathrm{~Pa}$. at 332, $341 \mathrm{~A} .2 \mathrm{~d}$ at 106.

8 See, e.g., Morasse v. Brochu, 151 Mass. 567, 568-69, 25 N.E. 74, 74-75 (1890) (excommunicated physician sued for damages that would be caused to his business because priest refused to minister to sick people while under the same roof as the physician); Fitzgerald v. Robinson, 112 Mass. 371, 381 (1873) (priest derided parishioner in front of an assembled congregation, proclaiming that "[h]e keeps a bad place of resort" and warning the parishioners to "keep away from it"); Bear, $462 \mathrm{~Pa}$. at 333, $341 \mathrm{~A} .2 \mathrm{~d}$ at 106 (shunned former church member found himself "unable to hire workers, obtain loans or market his produce"); Heinrichs v. Wiens, 31 D.L.R. 94, 97 (Sask. 1916) (shunned member of a Mennonite congregation brought an action against church officers for boycotting his business); cf. Lide v. Miller, 573 S.W.2d 614, 614-15 (Tex. Civ. App. 1978) (dentist sued elders of church claiming that they had injured his dental practice by reading a statement of his alleged misconduct to the assembled congregation).

374 U.S. 398, 406 (1963) ("[N]o showing merely of a rational relationship to some colorable state interest would suffice; in this highly sensitive constitutional area, [o]nly the gravest abuses, endangering paramount interests, give occasion for permissible limitation.' " (quoting Thomas v. Collins, 323 U.S. 516, 530 (1945))). The Court has articulated this standard in many different ways since Sherbert. See, e.g., United States v. Lee, 455 U.S. 252, 257-58 (1982) (stating that a state may regulate religious liberty if the regulation is "essential to accomplish an overriding governmental interest"); Thomas v. Review Bd., 450 U.S. 707, 718 (1981) ("The state may justify an inroad on religious liberty by showing that it is the least restrictive means of achieving some compelling state interest."); Wisconsin v. Yoder, 406 U.S. 205, 215 (1972) ("[O]nly those interests of the highest order and those not otherwise served can overbalance legitimate claims to the free exercise of religion."). 
state interest in regulating the behavior that gives rise to common law torts regarding marital and business relations is sufficient to override blanket claims of free exercise immunity by religious groups that shun former members. Courts should not read Sherbert to protect all forms of shunning, but instead should weigh the religious concerns of both parties to a shunning dispute before determining whether either party's behavior is protected under the free exercise clause. Surprisingly, no court has ever considered this approach. The free exercise rights of persons who are shunned have been ignored.

Finally, this Comment argues for a different test when religious shunning is an issue in child custody disputes. This new test would require custody decisions to be made on a religion-blind basis unless the shunning of one parent by the other threatens substantial harm to the child.

\section{Constitutional Background}

The first amendment to the United States Constitution provides that "Congress shall make no law respecting an establishment of religion, or prohibiting the free exercise thereof."10 This guarantee is applicable to the states through the fourteenth amendment. ${ }^{11}$ Government is thus under dual constraints when it acts in ways that affect religion. ${ }^{12}$ Too much accommodation of a particular religion, or of religion in general, may constitute an unconstitutional "establishment" of religion. ${ }^{13}$ A widely publicized example of a governmental "establishment" of religion is mandatory school prayer. ${ }^{14}$ On the other hand, facially neutral government regulations will often place a burden upon a partic-

10 U.S. Const, amend. I.

11 See Cantwell v. Connecticut, 310 U.S. 296, 303 (1940) ("We hold that the [state] statute, as construed and applied to the appellants, deprives them of their liberty without due process of law in contravention of the Fourteenth Amendment. The fundamental concept of liberty embodied in th[e Fourteenth] Amendment embraces the liberties guaranteed by the First Amendment.").

${ }_{12}$ See id. ("On the one hand [the First Amendment] forestalls compulsion by law of the acceptance of any creed ..... On the other hand, it safeguards the free exercise of the chosen form of religion.").

${ }_{13}$ See, e.g., Abington School Dist. v. Schempp, 374 U.S. 203, 226 (1963) ("[I]t is not within the power of government to invade [the individual heart and mind], whether its purpose or effect be to aid or oppose, to advance or retard."); McCollum v. Board of Educ., 333 U.S. 203, 209-12 (1948) (holding that a program permitting children in public schools to be released for religious education purposes violated establishment clause of the first amendment).

14 See Engel v. Vitale, 370 U.S. 421,424 (1962) (striking down on establishment clause grounds state-mandated school prayer). See generally J. LAUBACH, ScHooL PRAYERS 1 (1969) (stating that the Engel decision "caused more public outcry than any other Supreme Court decision in recent history"). 
ular religion's practices, thus interfering with the "free exercise" of religion. For example, state compulsory education laws requiring parents to keep their children in school until the age of sixteen have been held to violate the free exercise rights of members of the Old Order Amish religion, whose beliefs forbid formal education beyond a certain age. ${ }^{15}$

\section{A. Government Regulation that Interferes with Religion}

\section{Early Cases: The Belief-Action Dichotomy}

As a matter of common sense, some minimal constraints upon the free exercise of religion are necessary. Most obvious are instances when a belief is manifested in action that causes harm to others. ${ }^{16}$ Early cases interpreting the free exercise clause seized upon the distinction between

15 See Wisconsin v. Yoder, 406 U.S. 205 (1972). But cf. United States v. Lee, 455 U.S. 252 (1982) (upholding the validity of a compulsory social security withholding tax against a free exercise challenge brought by Old Order Amish). The Lee court said that "[t]he state may justify a limitation on religious liberty by showing that it is essential to accomplish an overriding governmental interest." Id. at 257-58. Presumably, the government's interest in the viability of the social security system is greater than its interest in compulsory education to age 16 .

${ }_{16}$ Perhaps the most dramatic examples of permissible state intervention with religious practices are cases upholding statutes that prohibit handling of poisonous snakes. In Hill v. State, 38 Ala. App. 404, 88 So. 2d 880 (1956), the defendant was a member of the Congregational Holiness Church, a faction of which believed in handling poisonous snakes as a test of faith. See id. at 408,88 So. $2 d$ at 883 . Hill's conviction-under a state statute prohibiting the handling of poisonous snakes in a manner that endangers the health or life of any person-was upheld over his free exercise claim. See id. at 411, 88 So. 2d at 886; see also Lawson v. Commonwealth, $291 \mathrm{Ky}$. 437, 446, 164 S.W.2d 972, 976 (1942) (affirming a conviction under a state statute prohibiting the handling of snakes in religious ceremonies on the ground that laws enacted to prohibit acts that endanger the safety of others are not repugnant to the constitutional protection of religious freedom); State ex rel. Swann v. Pack, 527 S.W.2d 99, 111 (Tenn. 1975) (snake handling case holding that the free exercise clause does not include the right to commit or maintain a nuisance), cert. denied, 424 U.S. 954 (1976); Harden v. State, 188 Tenn. 17, 25, 216 S.W.2d 708, 711 (1948) (affirming a conviction under a snake handling statute on the ground that prohibitions of dangerous acts that do not interfere with an individual's conscience or beliefs do not violate constitutionally protected religious liberties).

The protection afforded the exercise of religious faith is ordinarily very high unless the safety of another person is threatened. See supra note 9; see also Prince v. Massachusetts, 321 U.S. 158, 177 (1944) (Jackson, J., concurring) ("I think the limits [on religious freedom] begin to operate whenever activities begin to affect or collide with liberties of others or of the public. Religious activities which concern only members of the faith are and ought to be free-as nearly absolutely free as anything can be."). But see Mayock v. Martin, 157 Conn. 56, 58-59, 245 A.2d 574, 575-76 (1968) (upholding the state's committal of an inmate because of concern that the inmate would cut off his foot if he believed that God commanded him to do so. The inmate had already removed one of his eyes and one hand because he believed he was a prophet), cert. denied, 399 U.S. 1111 (1969). "The freedom to act must have appropriate definition to preserve the enforcement of that protection." Id. at 64, 245 A.2d at 578 . 
belief and action in order to assert broad governmental power to regulate religious conduct. ${ }^{17}$ For example, the Mormon polygamy cases sustained territorial regulations that proscribed polygamous marriage, ${ }^{18}$ placed significant burdens upon belonging to a group that advocated polygamous marriage, and even proscribed advocating polygamous marriage. ${ }^{19}$ The Court upheld these regulations even though the Mormons asserted that polygamous marriage was an integral part of their religious faith. ${ }^{20}$

This sharp doctrinal distinction between belief and action had two major weaknesses. First, the Constitution protects free exercise of religion, not merely free belief. ${ }^{21}$ Second, conduct is an integral part of most belief systems. Unlimited government power to regulate conduct could effectively obliterate the right to worship. ${ }^{22}$

2. The Substantial Interest Test: Increased Protection for Religious Conduct

Recent cases have enunciated a standard that is more protective of the religious practices of individual claimants. ${ }^{23}$ In Wisconsin $v$. Yoder, ${ }^{24}$ the Supreme Court held that a Wisconsin compulsory education statute ${ }^{25}$ violated the right of the Old Order Amish to raise their children in their religious tradition, ${ }^{26}$ which emphasized practical training after the child had attended eighth grade. ${ }^{27}$ Once it had determined that the Amish claim to free exercise was legitimate, ${ }^{28}$ the Court balanced the state's interest in compulsory education against the right of the Amish to pursue their time-honored beliefs: "[W]e must searchingly

${ }^{17}$ See, e.g., Reynolds v. United States, 98 U.S. 145, 164 (1878) ("Congress was deprived of all legislative power over mere opinion, but was left free to reach actions which were in violation of social duties or subversive of good order.").

18 See id. at 165-66.

18 See Davis v. Beason, 133 U.S. 333, 346-47 (1890) (upholding an Iowa election law that required all voters to swear under oath that they would not teach others to commit bigamy or polygamy).

${ }_{20}^{20}$ See id. at 345; Reynolds, 98 U.S. at 166-67.

21 See Freeman, A Remonstrance for Conscience, 106 U. PA. L. REv. 806, 818 (1958) (arguing that the Framers did not intend for government to have unbridled authority to regulate conduct).

${ }^{22}$ See, e.g., Wisconsin v. Yoder, 406 U.S. 205, 217 (1972) (noting the interdependence between Amish "religious beliefs and what we would call today "life style" before vindicating the Amish claim to exemption from state compulsory education laws).

23 See supra note 9 .

24406 U.S. 205 (1972).

${ }^{25}$ See WIS. STAT. $\S 118.15$ (1969), reprinted in Yoder, 406 U.S. at 207 n.2.

${ }^{26}$ See Yoder, 406 U.S. at 219.

27 See id. at 211.

28 See id. at 215-19. 
examine the interests that the State seeks to promote by its requirement for compulsory education to age 16, and the impediment to those objectives that would flow from recognizing the claimed Amish exemption."28

In Sherbert $v$. Verner, ${ }^{30}$ the Court considered the claim of a Seventh Day Adventist who had been fired because she refused to work on Saturday. ${ }^{31}$ She had been offered other jobs, but had not accepted because they also entailed work on Saturdays. ${ }^{32}$ She subsequently applied for, and was refused, state unemployment benefits because state law required an unemployed person to accept a job that was offered to her and for which she was qualified. ${ }^{33}$ The plaintiff claimed that this restriction violated her right to exercise freely her religion, which required her to worship on Saturdays. ${ }^{34}$ The Court reviewed the state statute in light of the plaintiff's free exercise claims, and stated:

[We have] rejected challenges under the Free Exercise Clause to governmental regulation of certain overt acts prompted by religious beliefs or principles, for "even when the action is in accord with one's religious convictions, [it] is not totally free from legislative restrictions." The conduct or actions so regulated have invariably posed some substantial threat to public safety, peace or order. ${ }^{35}$

Thus, the Court required the state to assert a "substantial" reason for regulating religious behavior. On its face, this is not a difficult standard to satisfy; almost any statute can be justified in terms of "public safety, peace or order."38 The Court went further, however, stating, "It is basic that no showing merely of a rational relationship to some colorable state interest would suffice; in this highly sensitive constitutional area, '[o]nly the gravest abuses, endangering paramount interests, give occasion for permissible limitation." "37

${ }^{29}$ Id. at 221.

so 374 U.S. 398 (1963).

31 See id. at 399.

32 See id. at 401.

s3 See id. The South Carolina Unemployment Compensation Act provided that, to be eligible for benefits, a claimant must have been "able to work and . . . available for work," S.C. CODE ANN. § 68-113(3) (Law. Co-op. 1962), reprinted in Sherbert, 374 U.S. at 400 n.3, and that a claimant was ineligible for benefits if she had "failed, without good cause . . . to accept available suitable work when offered [her] by the employment office or the employer. . ." S.C. CODE ANN. § 68-114(3)(a)(ii) (Law. Co-op. 1962), reprinted in Sherbert, 374 U.S. at 400 n.3.

${ }^{34}$ See Sherbert, 374 U.S. at 401.

35 Id. at 403 (quoting Braunfeld v. Brown, 366 U.S. 599, 603 (1961)).

${ }^{36} I d$.

37 Id. at 406 (quoting Thomas v. Collins, 323 U.S. 516, 530 (1945)). 
In Hobbie v. Unemployment Appeals Commission, ${ }^{38}$ the Court reaffirmed the balancing test employed in Sherbert. Upholding another Seventh-Day Adventist's free exercise challenge to an unemployment benefit law, the Court asserted that "such infringements must be subjected to strict scrutiny and could be justified only by proof by the state of a compelling interest." "s9 Thus, even for facially neutral statutes, state infringements upon religious liberty are given "strict scrutiny," and the state must have a "compelling interest" to justify their application.

\section{The "Compelling Interest" Test Presents Special Difficulties in Shunning Cases}

Although the standards evolved in Sherbert and Hobbie are not entirely clear, they provide a starting point for meaningful debate when state regulations threaten the free exercise of religion. Different considerations apply, however, when the free exercise clause is asserted as a defense to common law claims for injuries caused by shunning.

Two problems are created by a free exercise defense to common law claims. First, Sherbert directs courts to examine the magnitude of the state's interest in uniform enforcement of the challenged statute. ${ }^{40}$ This is a relatively easy task in cases involving laws and regulations, because statutes often have some legislative history that reflects the state interests involved. ${ }^{41}$ In contrast, when a religious group asserts a free exercise defense against a common law claim such as alienation of spousal affection, ${ }^{42}$ the state's interests are more likely to be obscure. ${ }^{43}$

In the common law context, most causes of action are aimed at resolving the rights of individuals or groups vis-à-vis each other. The state is not a party to the suit; its interests are represented by the court. Consequently, the standard enunciated in Sherbert and Hobbie, couched in terms of state interests, requires rethinking in the common law context. The state interest at stake in a common law action is the state's interest in providing a cause of action for a given tort. To satisfy

38480 U.S. 136 (1987).

s8 Id. at 141 .

40 See supra text accompanying notes 35-36.

41 Even if the statute's legislative history is inadequate, when a statute is challenged, the state will be a party to the dispute and therefore will be in a position to present its interests directly to the court.

42 See Restatement (SECOND) of ToRTs $\S 683$ (1977) (defining the tort of alienation of spousal affection as a direct interference with the marital relationship).

43 Consider, for example, the problem of weighing the state's interest in the context of a tort claim for alienation of spousal affection, see id., filed against a religious group as a result of its shunning practice. 
the Sherbert and Hobbie standard, the state interest must be compelling. Thus, if we assume that the policy underlying the tort of alienation of affection, for example, is concern for the stability of family relationships, then the court must ask itself whether it has a compelling interest in providing relief to plaintiffs who have been alienated from their spouses. It seems reasonable to say that state interests will be recognized as compelling more often in cases involving statutes, in which the state has manifested its interest, than in cases in which the court must find compelling its own role in common law actions between private parties.

The second difficulty in applying the Sherbert rationale to shunning cases, is that free exercise issues will almost always apply to both parties. For example, imagine that a woman has been a member of a religious group for ten years. During that time, she has married, had children, and built a business that depends largely on trade with members of the group. The woman becomes embroiled in a doctrinal dispute with the group, and the group expels her. According to the group's beliefs, all persons expelled must be shunned. Therefore, even though the woman's husband has great love for his wife, the group elders order him, on pain of expulsion, to cease all physical and emotional contact with her. The children are also instructed to shun their mother, and individual members of the group stop doing business with her. The marriage ends in divorce and the woman sues the group and the elders for alienation of her spouse's affection. The group, however, responds with a free exercise defense: by shunning the plaintiff, it was merely practicing what it believed.

If the court allows the woman's suit to proceed and requires the group to pay tort damages to the wife, it burdens the group's free exercise of religion. On the other hand, the woman may claim that she was exercising her own religious beliefs by disputing the group's religious principles. ${ }^{44}$ Consequently, for the court to deny her a cause of action

14 The case of Robert Bear, an excommunicated Mennonite, is illustrative. His excommunication and shunning resulted, ironically, in part from his disagreement with the shunning practice itself. See R. BEAR, supra note 5, at 5. Both parties to the Bear dispute were exercising their religious beliefs, yet only the "established" church was able to avail itself of first amendment protection.

A meaningful counterpoint to Bear's case can be drawn from Wooley v. Maynard, 430 U.S. 705 (1977), in which a Jehovah's Witness appealed his conviction under a New Hampshire statute for covering the state motto "Live Free or Die" on his automobile license plate. Maynard claimed that the motto was repugnant to his religious beliefs and that the statute violated his right to free exercise. See id. at 707. The state advanced a "conscientious" justification for the logo, arguing that it promoted appreciation of history, individualism, and state pride. See $i d$. at 716 . The court held the state statute unconstitutional as applied to Maynard. See id. at 717.

If we compare Maynard to Bear's case, a problem becomes apparent. Although 
would burden her right to free exercise, just as a burden would be placed upon the religious group if the court had recognized her cause of action. $^{45}$

One possible objection to the conclusion that the group and the individual have equivalent free exercise concerns is that the religious group can show state action, but the individual cannot. The religious group could argue that its religious belief, which required shunning, would be burdened by state action if the state court recognized the wo-

Maynard was able to employ the free exercise clause defensively against the state, Bear would have had considerable difficulty prevailing against the shunning practice of his church, even though in both cases the lone dissenting individual was acting upon his religious beliefs.

45 The message sent by the court would be that once the woman joins a group that practices shunning, she is effectively foreclosed from altering her beliefs. The impact of this result is magnified by the fact that a religious group may change its doctrine at any time before, during, or after a member leaves, and may retroactively impose punishment. This was precisely the situation in Paul v. Watchtower Bible and Tract Soc'y of N.Y., Inc., 819 F.2d 875, 876 (9th Cir.), cert. denied, 108 S. Ct. 289 (1987), in which Paul voluntarily withdrew from the Jehovah's Witnesses in 1975 , only to have the governing body of the church amend its rules in 1981 to provide for the shunning of persons who had left voluntarily. See id. at 877 . Paul subsequently was shunned and brought a legal action against her former church for the harm she had suffered.

The reason for the Paul court's indifference to the Witness's shift in religious belief is illustrated by Presbyterian Church in the United States v. Mary Elizabeth Blue Hull Memorial Presbyterian Church, 393 U.S. 440 (1969) [hereinafter Hull]. Hull involved a property dispute between the general church and some of its local factions. Under the applicable state law, the dispute was to be resolved by a "jury decision as to whether the general church abandoned or departed from the general tenets of faith" it had previously held. See id. at 441 . Justice Brennan, writing for the Court, rejected the so-called "departure-from-doctrine rule" because it violated the first amendment: "If civil courts undertake to resolve [doctrinal] controversies in order to adjudicate the property dispute, the hazards are ever present of inhibiting the free development of religious doctrine and of implicating secular interests in matters of purely ecclesiastical concern." Id. at 449. One commentator has pointed out that the practical effect of $\mathrm{Hull}$ is that a church may completely change its position on any religious, political, civil, economic, or social issue without interference from the courts. See L. Pfeffer, Religion, State and the Burger Court 266 (1984). As applied to the Paul case, this result is unsettling. Paul joined and left the church while one set of rules was in effect; under $\mathrm{Hull}$, when the church later changed the rules to her detriment, she had no legal recourse.

Justice Harlan's concurring opinion in Hull offers an alternative ratio decidendi. Harlan did not understand Justice Brennan's opinion to preclude a court from "enforcing a deed or will which expressly and clearly lays down conditions limiting a religious organization's use of the property which is granted." Hull, 393 U.S. at 452 (Harlan, J., concurring). Likewise, a church's treatment of former members should be limited to the conditions in force when the former members belonged to the church. This approach would not inhibit the free development of religious doctrine because the church would remain free to alter its doctrine at any time without altering its rights with respect to existing members; church members would be free to resign in the event that their church changed its doctrine without warning. It would also avoid the result in Paul, which permitted the majority to exercise control over its members past and present. Even if such power is never exercised, its existence could quell dissent and doctrinal development within the church itself. 
man's tort claim. ${ }^{48}$ At the same time, the religious group could argue that the woman's free exercise rights were burdened solely by the actions of the group, which is a private actor, so that no state action is implicated. This distinction, however, lacks substance. If the court is a state actor when it upholds the church member's tort claim, then it is a state actor when it upholds the religious group's free exercise defense. ${ }^{47}$

Another likely response to the woman's complaint is that she assumed the risk of shunning when she joined the group. The case law, however, does not uniformly bear out this contract-type model in practice. ${ }^{48}$ In fact, churches are free to change their doctrine at will, and church members cannot complain to the courts. ${ }^{49}$

The very nature of shunning disputes between an individual and a religious group is such that they will likely involve the free exercise

46 This argument was accepted by the Supreme Court in New York Times Co. v. Sullivan, 376 U.S. 254 (1964). In that case, the Court concluded that a state court's recognition of a civil claim constituted "state action" under the fourteenth amendment:

Although this is a civil lawsuit between private parties, the [state] courts have applied a state rule of law which petitioners claim to impose invalid restrictions on their constitutional freedoms of speech and press. It matters not that the law has been applied in a civil action and that it is common law only, though supplemented by statute. The test is not the form in which state power has been applied but, whatever the form, whether such power has in fact been exercised.

Id. at 265 (citations omitted); see also Lugar v. Edmondson Oil Co., 457 U.S. 922, 942 (1982) (private party creditor's use of a state system to attach debtors' property upon ex parte application to state authorities constitutes state action); Shelley v. Kraemer, 334 U.S. 1 (1948) (state court enforcement of racially restrictive covenant in a property deed constitutes state action). The Paul court applied this principle in the religious context. See Paul, 819 F.2d at 880 ("[T] he application of tort law to activities of a church or its adherents in their furtherance of their religious belief is an exercise of state power.").

47 It is debatable whether a state court engages in "state action" for the purposes of the first and fourteenth amendments by recognizing a common law claim. The only court that addressed this question in a shunning case concluded that state action was present. See Paul, 819 F.2d at 880 ("State laws whether statutory or common law, including tort rules, constitute state action." (citing New York Times Co. v. Sullivan, 376 U.S. 254 (1964))). Other courts that have decided shunning cases proceeded under the assumption that their application of state common law to a religious group would constitute state action. See, e.g., Bear v. Reformed Mennonite Church, 462 Pa. 330, 335, 341 A.2d 105, 108 (1975) (concluding that the first amendment might be implicated should the court recognize plaintiff's claim).

48 Cf. Hull, 393 U.S. at 449-50 (stating that the first amendment prohibits courts from evaluating issues involving church doctrine). Even if a contract model were accepted, its application in cases involving retroactive shunning would be troublesome. For example, in Paul, the plaintiff resigned from the church at a time when the church's doctrine contained no explicit sanction for such action. See Paul, 819 F.2d at 877. Indeed, it was not until six years after Paul's resignation that the church altered its doctrine and began to shun members who left the church. See id. Thus, application of the contract model to Paul would entail making the untenable argument that part of Paul's "contract" was to agree to a practice that the church had not yet adopted.

49 See supra notes 44-45. 
rights of both parties. ${ }^{50}$ For some reason, this fact has never been recognized by courts or asserted by litigants in shunning disputes. If a court is willing to recognize the free exercise defense asserted by religious groups that practice shunning, then it should also recognize that a member who left the group may be protected by the free exercise clause. Although court recognition of the plaintiff's claim would place some burden upon the group's shunning behavior, recognition of the group's defense will burden the decision of a member to leave, at least from groups that sanction "shunning" of former members. The free exercise clause should not protect the group more than it protects the individual members of the group. ${ }^{\mathbf{} 1}$

There are two possible solutions to the shunning dilemma. First, courts could avoid the issue altogether by refusing to find state action when they recognize a tort cause of action between private litigants. Under this approach, courts would decide the underlying substantive legal issues of the tort claim without determining whether the church members were following their religious beliefs. Although this approach avoids the morass of conflicting "rights" mentioned above, it is not consistent with current authority that finds state action when courts recognize common law tort claims. ${ }^{\text {s2 }}$

If, on the other hand, the court concludes that the state action requirement is satisfied when it recognizes a common law cause of action, then the Sherbert test comes into play. The Sherbert test, however, presents difficulties in shunning cases in which free exercise rights exist on both sides of a dispute. Although courts need not reject the Sherbert test in shunning cases, they must be mindful of the special concerns presented by such cases.

\section{Shunning, Disfellowshipping, and Excommunication}

Because shunning cases do not arise often, and because of the un-

so Cf. Bear, $462 \mathrm{~Pa}$. at $331,341 \mathrm{~A} .2 \mathrm{~d}$ at 106 (individual was shunned because of a doctrinal dispute with his church).

BI That the first amendment protects individuals at least as much as it protects groups is implicit in the establishment clause, which prohibits government from furthering the goals of religious groups. See supra notes 13-14 and accompanying text. Furthermore,

[T] $T$ he guarantee of religious liberty embodied in the Free Exercise Clause affirmatively requires government to create an atmosphere of hospitality and accommodation to individual belief or disbelief. ... . [O]ur Constitution commands the positive protection by government of religious freedom-not only for a minority, however small-not only for the majority, however large-but for each of us.

Sherbert, 374 U.S. at 415-16 (Stewart, J., concurring in result).

${ }^{52}$ See supra note 47 and accompanying text. 
usual dynamics of these disputes, it is not surprising that courts have applied the Sherbert test inconsistently. ${ }^{83}$ This Part examines shunning and the types of disputes that grow out of it in order to provide an overview of shunning and give the reader a framework in which to apply the Sherbert rationale.

\section{A. The Purposes of Shunning}

The unity of any group that adheres to a given body of religious ideas is dependent to some extent upon its members' fear of being forced to live apart from the group. ${ }^{54}$ Generally, the more a religious group is considered to be in the minority, the greater its need for strong sanctions against deviations from the faith. ${ }^{.5}$ There are a number of common sense explanations for this phenomenon. First, assuming that smaller religious sects are comprised mainly of converts from other, more "mainstream" sects, the threat of sanctions may persuade converts to remain faithful to their new sect after the first blush of inspiration wears off. This appears to have been the case with the Jehovah's Witnesses, who adopted the practice of "disfellowshipping" sometime during the middle part of this century-in apparent response to the group's rapid growth. ${ }^{58}$ Furthermore, converts entering a new sect fre-

ss Compare, e.g., Paul v. Watchtower Bible and Tract Soc'y of N.Y., Inc., 819 F.2d 875, 883 (9th Cir.) ("[T] cient threat to the peace, safety, or morality of the community . . . to warrant state intervention."), cert. denied 108 S. Ct. 289 (1987) with Bear v. Reformed Mennonite Church, $462 \mathrm{~Pa}$. 330, 334-35, 341 A.2d 105, 107-08 (1975) (recognizing that "the First Amendment may present a complete and valid defense to the allegations of the complaint," but nevertheless permitting plaintiff's cause of action for shunning because "the 'shunning' practice . . . may be an excessive interference within areas of "paramount state concern' . . . which the courts of this Commonwealth may have authority to regulate").

B4 Cf. B. RAven \& J. RuBin, supra note 1, at 319-20 (Strong pressures toward uniformity exerted by groups tend to depend on the following characteristics: (1) little discrepancy of opinion within the group; (2) greater degree of relevance of the disputed opinion to the functioning of the group; (3) high group cohesiveness based upon close interpersonal relationships; (4) exhibition of certain personality characteristics by members of the group, including authoritarian personalities, low self-esteem, self-blaming, a high need for affiliation, low intelligence, anxiety, and low tolerance for ambiguity; and (5) cultural factors that seem to exist in societies that have birth and death rates that are both either high or low.).

b5 See id. at 329 (discussing how deviants from one group will seek more compatible alternative groups). The Mennonites and the Jehovah's Witnesses comprise relatively small, but cohesive, segments of their surrounding populations. The experiences of Robert Bear illustrate the strength of pressures to conform in the Mennonite church: "I should have known how submissive the church had [my wife] to do its bidding out of fear of losing 'unity' with the one 'pure' body, for her to turn so completely against a husband she had lived with for thirteen years." R. BEAR, supra note 5 , at 38 .

${ }^{36}$ See M. Penton, Apocalypse Delayed: The Story of Jehovah's WitNESSES 84-90 (1985). 
quently retain strong ties to family or other groups outside of the new religion. A strong sanction against leaving or backsliding will counteract the temptations and pressures applied by family members and friends to convince the recent convert to abandon the new sect. ${ }^{.57}$

A second explanation for shunning is that it reinforces important distinctions between members of the group and nonmembers. ${ }^{58}$ This rationale seems most applicable to groups with lifestyles that differ significantly from the surrounding culture. Hence, the practice of meidung, or shunning, is deeply rooted in the Old Order Amish and Reformed Mennonite churches, for whose members a distinctive lifestyle is part and parcel of their religion. ${ }^{59}$ Indeed, for religions premised upon resisting the influences of the changing world, it is no surprise that the distinction between "us" and "them" assumes critical importance. ${ }^{80}$

\section{B. Shunning Cases and Application of the Sherbert Test}

The purpose of this Section is to provide an overview of different types of shunning cases. It is divided into three Subsections. The first Subsection discusses cases in which shunned persons sue their church for harm done to their family relationships; the second Subsection discusses harm to business relationships; and the third Subsection examines the unique issues raised when shunning results in divorces that lead to child custody disputes. The Section concludes that courts gener-

B7 Cf. Van Schaick v. Ghurch of Scientology, 535 F. Supp. 1125, 1139 (D. Mass. 1982) (plaintiff alleged that church "exhorted her to sever family and marital ties and to depend solely on the Church for emotional support"); Turner v. Unification Church, 473 F. Supp. 367, 378 (D.R.I. 1978) (plaintiff alleged that church had "deprived her of the love and affection of her parents and friends"), affd per curiam, 602 F.2d 458 (1st Cir. 1979).

${ }^{68}$ See B. Raven \& J. Rubin, supra note 1, at 319. Robert Bear's comments illustrate how shunning can be used to isolate "sinful" members of a group. "Because I have been excommunicated I am considered to be more sinful than if I had never known 'the truth." "R. BEAR, supra note 5, at 10.

59 "To the Amish there is a divine spiritual reality, the Kingdom of God, and a Satanic Kingdom that dominates the present world. It is the duty of a Christian to keep himself 'unspotted from the world' and separate from the desires, intent, and goals of the worldly person." J. HosTetLER, supra note 5, at 48; see also 1 THE MENNONITE ENCYCLOPEDIA 657 (1955) ("The sincere efforts of its members to live scrupulously righteous lives in a sinful world often made Mennonite communities conspicuous."); Weber, Religious Rejections of the World and Their Directions, in Essays IN SociolOGY 323-59 (1958) (arguing that a dualistic vision of the world provides a basis for rejecting outsiders and thus shapes social behavior).

${ }_{\text {oo }}$ See supra note 58; see also 7 EnCYClopedia of ReLIGION 565 (1987) ("[A Jehovah's] Witness must keep apart from the world and must obey only those secular laws and follow only those practices of faith that are in conformity with the society's understanding of the Bible."). 
ally have done rough justice in shunning cases, but for the wrong reasons. The free exercise rights of the victim of shunning should be considered along with the rights of the church.

\section{Harm to Family Relationships}

Shunning severs all contact between members of the group and the outcast. ${ }^{61}$ The effect of shunning often depends upon the shunned person's relationship with the group. To the member who is a relatively recent convert having minimal economic ties to the group, shunning may mean only the loss of a few close friends. ${ }^{62}$ Conversely, for the member who was born into the sect or has an extensive social or economic commitment to the group, shunning can cause much greater harm. For example, if a husband leaves the sect while his wife remains involved, the sect may require the wife to shun the husband. ${ }^{63}$ The results of this type of shunning vary, but members are commonly forbidden from physical or social contact with a shunned spouse. ${ }^{64}$ Furthermore, the children may also be required to choose between the member-parent and the shunned parent. ${ }^{65}$ In most of the cases that reach the courts, this type of interspousal shunning results in divorce. ${ }^{66}$ The facts of these cases illustrate the unique legal issues involved in familial shunning cases.

\section{a. Bear v. Reformed Mennonite Church ${ }^{67}$}

The Reformed Mennonite Church, as one if its fundamental principles, teaches that an excommunicated member should be shunned. ${ }^{88}$ The shunning includes a total boycott of the individuals by their families. Bishop Daniel Musser of the Reformed Mennonite Church spoke of the practice this way:

All company necessary to admonish, or to minister to their necessities, should be freely given; but eating social meals, or keeping social company, or having commercial in-

S1 See supra note 5 and accompanying text.

${ }^{62}$ See, e.g., Paul v. Watchtower Bible and Tract Soc'y of N.Y., Inc., 819 F.2d 875,877 (9th Cir.) (Paul, who was not born into the religion, alleged that the church's shunning deprived her of her friends' affection), cert. denied, 108 S. Ct. 289 (1987).

63 See supra notes 5-6 and accompanying text.

see $i d$.

6s See supra note 7 and accompanying text.

${ }^{66}$ See supra note 6 .

67462 Pa. 330, 341 A.2d 105 (1975).

${ }^{68}$ See R. BEAR, supra note 5, at 2-4 (discussing shunning in the context of the Reformed Mennonite Church's continued adherence to the marriage-breaking doctrine). 
tercourse, the Word of God forbids; and when it is demanded, must be denied under all circumstances. . . . And thou shalt stone him with stones, that he die [Deut. XIII]. Surely, this command disturbed the sacred family relation much more seriously than the gospel command. Besides, the espousels [sic] of Christ are above the espousels [sic] of man. The duties of wedlock must ever yield to our duties to God. To be faithful to God, is the first duty of man; and consequences can never enter into consideration. ${ }^{68}$

Robert Bear was excommunicated from his church because he had criticized the teachings and practices of the church and its bishops. ${ }^{70}$ During his time as a member of the church, he had married another member, and they had six children. Bear filed a two-count complaint against the Reformed Mennonite Church and two of its bishops, ${ }^{71}$ alleging that his business and family were in collapse because church officials were causing the entire community to shun him. ${ }^{72}$ The church officials demurred without filing any responsive pleadings, claiming that Bear's complaint failed to state a cause of action. ${ }^{73}$ The trial court sustained the demurrer. ${ }^{74}$

On appeal, the question before the court was whether the law said " "with certainty that no recovery is permitted." " "75 The court applied the Sherbert test to hold that, under the facts pled by Bear, it may be possible for a state court to grant relief:

In our opinion, the complaint ... raises issues that the "shunning" practice of appellee church and the conduct of the individuals may be an excessive interference within areas of "paramount state concern," i.e. the maintenance of marriage and family relationship, alienation of affection, and the tortious interference with a business relationship, which the

${ }^{69}$ Id. at 4 (quoting D. Musser, The Reformed Mennonite Church 360-61 (1873)). The scriptural origin of this belief is Matthew 18:15-17: "If he neglect to hear the church, let him be unto thee as a heathen man and a publican." See J. HosterLER, supra note 5, at 62 .

${ }_{70}$ See Bear, $462 \mathrm{~Pa}$. at 332, $341 \mathrm{~A} .2 \mathrm{~d}$ at 106.

71 See id. Ironically, one of the bishops was the plaintiff's brother-in-law. See id. at 333, 341 A.2d at 106; R. BEAR, supra note 5, at 32 .

${ }_{72}$ See Bear, $462 \mathrm{~Pa}$. at 333, $341 \mathrm{~A} .2 \mathrm{~d}$ at 106 . Bear alleged that his farming business had lost at least fifty thousand dollars because of his difficulties with the church. See R. BEAR, supra note 5 , at 76.

${ }^{73}$ See Bear, $462 \mathrm{~Pa}$. at 333, $341 \mathrm{~A} .2 \mathrm{~d}$ at 106-07.

74 See id. at 333, 341 A.2d at 107.

${ }^{76} I d$. at 334,341 A.2d at 107 (quoting Buchanan v. Brentwood Fed. Sav. \& Loan Ass'n, 457 Pa. 135, 139, 320 A.2d 117, 120 (1974) (quoting Clevenstein v. Rizzuto, $439 \mathrm{~Pa}$. 397, 401, 266 A.2d 623, 625 (1970))) (emphasis added by Buchanan court). 
courts of this Commonwealth may have authority to regulate, even in light of the "Establishment" and "Free Exercise" clauses of the First Amendment. ${ }^{76}$

The rationale for the court's decision lay in the language in Sherbert limiting state interference with the free exercise of religion to areas of paramount state concern. ${ }^{77}$ Bear cited family relationships, alienation of affection, and tortious interference with a business relationship as matters of state concern that could potentially override free exercise claims by defendants. ${ }^{78}$ Bear thus stands for the proposition that the first amendment is not an absolute defense to common law liability for shunning activities. Put another way, application of state tort law to shunning cases does not necessarily violate the free exercise clause.

Bear, however, did not address whether the potential burden upon Bear's own free exercise could enter into the balance. Bear left the church because he disputed its religious doctrine, and he was penalized severely for his divergent views. Had Bear upheld the church's demurrer, allowing the church's action to go unremedied, it would have burdened Bear's decision to leave, much as it could be said to have burdened the church's shunning practice to deny the church an absolute free exercise defense. ${ }^{79}$

\section{b. Carrieri v. Bush ${ }^{80}$}

In Carrieri, a husband brought an action for alienation of his wife's affections against the pastor and elders of an unidentified religious sect. ${ }^{81}$ The trial court dismissed the case at the close of the husband's evidence, and the husband appealed. ${ }^{82}$

The facts of Carrieri are similar to the those of Bear. Mr. Carrieri began attending a new church with his wife, but stopped after a short time because he " 'couldn't quite agree with [the pastor's] style of preaching." "Bs Carrieri's wife, however, continued to attend, and her attitude toward him gradually changed. ${ }^{84}$ Carrieri testified: " " $[\mathrm{H}] \mathrm{er}$ attitude became cold toward me. She treated me as a boarder, like she no

78 Id.

77 See id. at 335, 341 A.2d at 107-08 (quoting Sherbert v. Verner, 374 U.S. 398, 406 (1963)).

78 See id. at 334,341 A.2d at 107.

70 See supra note 44 and accompanying text (discussing the free exercise rights of plaintiffs in shunning cases).

so 69 Wash. 2d 536, 419 P.2d 132 (1966).

${ }^{81}$ See id. at 538-39, 419 P.2d at 133-34.

${ }^{82}$ See id. at 538, 419 P.2d at 133-34.

Bs Id. at 539, 419 P.2d at 134 (quoting testimony of Carrieri at trial).

st See id. 
longer loved me, and she would come right out and tell me that." "\$85 Finally, Carrieri confronted the pastor about his wife's changed attitude and asked him to help, rather than hinder, their relationship. "Immediately [the pastor's] eyes got big and large and he said immediately, he said, "No. You're full of the devil." My wife and children were there. He said, "She does not have to listen to you. . . . [Inga,] don't listen to your husband." " "B6 Carrieri also alleged that his wife had taken an oath, administered by the pastor, that she would not leave the church; that the pastor told her that she would die if she left the church; that the pastor concealed his wife's whereabouts when she moved out of the house; and that some of the church elders had advised her to divorce Carrieri. ${ }^{87}$

As a preliminary matter, the Supreme Court of Washington held that Carrieri had successfully presented a prima facie case of alienation of affections. ${ }^{88}$ The court then addressed whether the defendants' acts were privileged or excepted from the general tort law because they were done in furtherance of a religious belief. ${ }^{80}$ It concluded that generally such acts would be protected, but that in this case the privilege was overcome because when "[i]ll will, intimidation, threats, or reckless recommendations of family separation directed toward alienating the spouses, [are] found to exist, [they] nullify the privilege and project liability." ${ }^{90}$ Thus, Carrieri went a step further than Bear by actually projecting tort liability onto the defendants for acts motivated by their religious beliefs, notwithstanding the fact that the defendants had interposed a free exercise defense. ${ }^{91}$ -

Carrieri's recognition of a spouse's "right to be reconciled"92 can be analogized to a shunned person's interest in making a religious decision without fear of retaliation by the church. Carrieri did not explicitly recognize the husband's freedom of choice as an important element

${ }^{85}$ Id. (quoting testimony of Carrieri at trial).

${ }^{88}$ Id. at 540-41, 419 P.2d at 135 (quoting testimony of Carrieri at trial).

87 See id. at 541-42, 419 P.2d at 135-36.

88 See id. at 544,419 P.2d at 137.

${ }^{89}$ See id. at 543, 419 P.2d at 137. The Restatement (Second) of ToRts $\S 686$ (1977) provides that some instances of alienation of affections are privileged. The Carrieri court relied on the RESTATEMENT (FIRST) OF TORTS $\S 686$ (1938), which is similar to the current version.

${ }^{80}$ Carrieri, 69 Wash. 2d at 545, 419 P.2d at 137.

91 Carrieri relied on the free exercise clause of the Washington State constitution. See id. at 544, 419 P.2d at 137 (citing WASH ConST. art. I, \& 11, amend. 34). Washington's free exercise clause provides protections "at least as generous as those of the federal constitution." Paul v. Watchtower Bible \& Tract Soc'y of N.Y., Inc, 819 F.2d 875, 880 (9th Cir.), cert. denied, 108 S. Ct. 289 (1987).

${ }^{92}$ Carrieri specifically recognized a "right of discordant spouses to become reconciled." Carrieri, 69 Wash. 2d at 544, 419 P.2d at 137. 
of its decision, but did so implicitly by recognizing his right to be reconciled. The court's approach allowed both the husband and the wife to choose freely without fear of unprincipled outside intermeddling in their marital relationship.

\section{c. Analysis of Carrieri and Bear}

The analysis of the shunning phenomenon presented by Bear and Carrieri may afford little protection to religious groups that actively practice shunning. Under this analysis, many state-recognized actions in tort could rise to the level of "paramount" state concern required by Sherbert. In this manner, the Sherbert test would become subjective. The nebulous nature of the policies embodied in common law causes of action makes it difficult for courts to determine the extent to which the state's objectives would be impeded by the recognition of a free exercise exception to a general tort principle. This is largely because courts define common law causes of action, such as alienation of spousal affection, in terms of individual rights, such as the right to be reconciled with one's spouse. ${ }^{93}$

Thus, the state's interest in the reconciliation of spouses is pitted against the church's right to shun. This collision of individual rights is quite different from the "classic" free exercise case, in which the lone individual pits her religious rights against a faceless and compassionless bureaucracy ${ }^{94}$ representing state interests often comprised of such tangible concerns as administrative efficiency ${ }^{95}$ or the solvency of a govern-

93 The "right to reconciliation" carries a special significance in the shunning context. Such a right provides for judicial scrutiny when religious groups interfere with reconciliation between individuals. In an analogous line of cases, courts have recognized membership in a religious group as a property "right," justifying judicial scrutiny in instances of alleged wrongful expulsion. See, e.g., Baugh v. Thomas, 56 N.J. 203, 208, 265 A.2d 675, 677 (1970) ("[E]xpulsion from a church or other religious organization can constitute a serious emotional deprivation which, when compared to some losses of property or contract rights, can be far more damaging to an individual."); Randolph v. First Baptist Church, 53 Ohio Op. 288, 291, 120 N.E.2d 485, 488-96 (Ct. C.P. 1954) (noting, in holding that plaintiff's expulsion was invalid because she had not been given a fair and impartial investigation as required by the church constitution, that church membership is a property right that can be reviewed by a court).

94 See, e.g., Hobbie v. Unemployment Appeals Comm'n, 480 U.S. 136 (1987) (Plaintiff sought religious exemption from state unemployment law denying her benefits because she was discharged for refusing to work on her Sabbath out of religious convictions adopted after commencing her employment.); Goldman v. Weinberger, 475 U.S. 503 (1986) (Air Force doctor sought religious exception to military dress code prohibiting the wearing of headgear, including a yarmulke, while indoors.).

${ }^{25}$ See, e.g., United States v. Lee, 455 U.S. 252, 258-259 (1982) (because a comprehensive national social security system that provided for voluntary participation would be almost impossible to administer, the governmental interest in assuring mandatory and continuous participation is very high). 
ment program. ${ }^{86}$ This difference suggests why courts that apply the Sherbert analysis to shunning cases rarely move beyond incantations of the "paramount" state interest language before applying general common law principles. The result is that free exercise claims are decided by appeal to the common law vernacular of ill will, malice, and the like. ${ }^{\text {g7 }}$

That is not to say that courts have universally adopted the stance suggested by Bear and Carrieri. Some courts tend to afford a nearabsolute immunity to activities conducted in the name of religion. ${ }^{98}$ This approach holds potential for tragic results in individual cases, however, because it does not provide for scrutiny of religious activity that may cause substantial harm. Examples of this approach will be discussed in the next part.

\section{d. Paul v. Watchtower Bible and Tract Soc'y of N.Y., Inc. ${ }^{98}$}

The plaintiff in Paul was a "disassociated" member of the Jehovah's Witnesses. ${ }^{100}$ As such, her status was similar to that of the plaintiffs in Bear and Carrieri, with the important distinction that Paul did not sue for alienation of affection. ${ }^{101}$ Paul alleged common law torts of

${ }^{90}$ See, e.g., id. at 258 (stating that mandatory participation in the social security program is indispensable to its fiscal vitality).

${ }_{97}$ The Supreme Court has developed a similar standard to deal with challenges to the decisions of ecclesiastical authorities. See, e.g., Serbian E. Orthodox Diocese v. Milivojevich, 426 U.S. 696, 709 (1976) ("[T]he First and Fourteenth Amendments mandate that civil courts shall not disturb the decisions of the highest ecclesiastical tribunal" absent "fraud or collusion.").

${ }^{88}$ See Paul v. Watchtower Bible and Tract Soc'y of N.Y., Inc., 819 F.2d 875 (9th Cir.), cert. denied, 108 S. Ct. 289 (1987); Gruwald v. Ben Zion Bornfreund, No. GV85-3338 (E.D.N.Y. Sept. 20, 1988).

98819 F.2d 875 (9th Cir.), cert. denied, 108 S.Ct. 289 (1987). Paul illustrates the difficulty of finding a meaningful standard to apply to cases, such as those involving shunning, in which state common law causes of action are asserted against religious organizations. In Paul, the Ninth Circuit did not apply the test it had previously formulated to test free exercise challenges to statutory restrictions. See Callahan v. Woods, 736 F.2d 1269, 1273 (9th Cir. 1984) (setting out the Ninth Circuit's test for whether a neutrally based statute violates the free exercise clause as considering (1) the magnitude of the statute's impact upon the exercise of the religious belief; (2) the existence of a compelling state interest justifying the burden on the exercise of the belief; and (3) the extent to which a recognition of an exemption from the statute would impede the objectives sought to be advanced by the state).

100 According to the doctrine of the Jehovah's Witnesses, disassociated members must be shunned. See Paul, 819 F.2d at 876-77; J. BERGMan, supra note 5, at xxiii.

101 See Paul, 819 F.2d at 877 . This distinction is relevant for a number of reasons. The Bear and Carrieri courts were both concerned with the state's compelling interest in "the maintenance of marriage and family relationship." Bear, $462 \mathrm{~Pa}$. at 334, 341 A.2d at 107; see also Carrieri, 69 Wash. 2d at 544-45, 419 P.2d at 137 (asserting that the free exercise of religious beliefs, although protected by the state constitution, does not grant license to "wrongfully interfere" with familial relationships). 
defamation, invasion of privacy, fraud, and outrageous conduct against her former church. ${ }^{102}$ The Ninth Circuit affirmed the district court's grant of summary judgment in favor of the church. ${ }^{103}$

Paul stands in sharp contrast to Carrieri, because both courts purported to apply Washington state law, yet reached different results. ${ }^{104}$ While it is possible to distinguish the two cases on a number of factual grounds, ${ }^{105}$ the fact remains that both courts applied Washington common law to cases involving conflicts between claims of intangible emotional harm and free exercise privilege. Furthermore, the Paul court noted that the Pennsylvania Supreme Court, in Bear, had "recently recognized a cause of action in tort arising from the practice of shunning,"106 but suggested that the Pennsylvania court had embarked upon an unconstitutional course: "Were shunning considered to be tortious conduct, the guarantee of the free exercise of religion would provide that it is, nonetheless, privileged conduct."107 The analysis that led the Ninth Gircuit to this conclusion warrants further consideration.

The court began by accepting shunning as a practice mandated by the Jehovah's Witnesses's religious beliefs, which are based on canonical texts that the court was not permitted to reinterpret. ${ }^{108}$ The court then asserted that the free exercise protections provided by the Washington and federal Constitutions are identical. ${ }^{109}$ The court also reasoned that judicial recognition of common law torts constitutes state ac-

Although Paul was married to a church member, she sought damages for defamation, invasion of privacy, fraud, and outrageous conduct. See Paul, 819 F.2d at 877 . She could claim to have been harmed only by the loss of friends. Her own family had been "disfellowshipped" before she chose to leave the Witnesses herself. See id. at 876 . Therefore, Paul does not fall directly under the Carrieri analysis, which deals with harm to family relationships.

102 See id. at 877.

103 See id. at 883.

104 Compare Paul, 819 F.2d at 878-80 (holding that, under Washington law, there was no need to determine whether Washington courts would grant relief for the alleged intentional torts because the defendants were privileged under the free exercise clause of the Washington and U.S. Constitutions) with Carrieri, 69 Wash. 2d at 54245, 419 P.2d at 136-37 (under Washington law, alienation of affections was actionable as an intentional tort despite its religious context).

108 Compare, e.g., Paul, 819 F.2d at 883 n.7 (no evidence that the members of the church had acted with malice) with Carrieri, 69 Wash. 2d at 545, 419 P.2d at 137 (case decided on the ground that the church members had acted maliciously); Paul, 819 F.2d at 877 (friends of plaintiff would not talk to her) with Carrieri, 69 Wash 2d at 539-42, 419 P.2d at 134-36 (plaintiff's relations with his wife grew worse until she divorced him).

${ }^{106}$ Paul, 819 F.2d at 878.

107 Id. at 879.

108 See id.

109 See id. at 880. 
tion, ${ }^{110}$ concluding that imposition of tort damages for shunning would constitute a direct burden upon religion by restricting the free exercise of the Jehovah's Witnesses' religious faith. ${ }^{111}$ Only after the court held "the practice of shunning not to constitute a sufficient threat to the peace, safety, or morality of the community as to warrant state intervention"112 did it look to the particulars of Paul's situation, ${ }^{113}$ concluding that the alleged intangible emotional harm did not "justify the imposition of tort liability for religious conduct."114

The court stated that it was appropriate to allow a free exercise defense to the church in this case, because Paul was a former member, and, as such, had impliedly consented to any action that might be taken against her by her former church. ${ }^{115}$ What the court did not point out in its discussion of Paul's "consent" is that the church had changed its policy respecting "disassociated" members after Paul left. ${ }^{116}$ In effect, the church unilaterally and retroactively withdrew Paul's right to associate with her friends. ${ }^{117}$ To say, as did the Ninth Circuit, that Paul's

110 See id.; see also supra notes $43-47$ and accompanying text (discussing state action as applied to shunning cases).

111 See Paul, 819 F.2d at 880-81.

112 Id. at 883.

113 See id. at 876-77.

114 Id. at 883 . The acts of which Paul complained included one occasion when a close childhood friend told Paul, "I can't speak to you. You are disfellowshipped." Id. at 887. On another occasion, Paul attended a Tupperware party at the home of a Witness only to be informed that the church elders had instructed the congregation not to speak to her. See id.

${ }^{115}$ See id. at 883. See generally C. Zollman, American Grvil Ghurch Law 223-24 (1917). Professor Zollman likens church membership to a contract:

[Church membership] is "one of contract" and is therefore exactly what the parties to it make it and nothing more. A person who joins a church covenants expressly or impliedly that in consideration of the benefits which result from such a union he will submit to its control and be governed by its laws and usages and customs whether they are of an ecclesiastical or temporal character to which laws, usages and customs he assents as to so many stipulations of a contract.

Id. (footnotes omitted); see also Rosicrucian Fellowship v. Rosicrucian Fellowship Nonsectarian Church, 39 Cal. 2d 121, 131-32, 245 P.2d 481, 487 (1952) (en banc) (citing Zollman to support a general rule that courts will not interfere in ecclesiastical matters), cert. denied, 345 U.S. 938 (1953).

${ }^{116}$ When Paul voluntarily left the Jehovah's Witnesses, there was no express sanction for withdrawing from the group; not until six years later did the Governing Body of Jehovah's Witnesses rule that disassociated members were to be shunned. See Paul, 819 F.2d at 877.

117 In Hobbie, the Supreme Court concluded that it was irrelevant that the plaintiff, who was challenging a state unemployment regulation, had converted to a new faith after two and one-half years on the job and as a result developed a conflict with her work schedule. See Hobbie v. Unemployment Appeals Comm'n, 480 U.S. 136 (1987). It is thus difficult to reconcile Hobbie, (an individual can change her beliefs and still assert a free exercise claim against the state), Hull, 393 U.S. 440 (1969), (permitting a church to change its doctrine at any time and still claim free exercise 
friends decided that they no longer wished to associate with her ${ }^{118}$ ignores the fact that her friends' "decision" was influenced by the threat that anybody who associated with Paul risked being disassociated herself. ${ }^{118}$

The Paul court's holding that state common law torts always impose an unconstitutional burden upon religious exercise, was unwarranted. In Paul, the Ninth Circuit fell prey to a distortion precisely opposite from the one that confronts courts dealing with an individual's free exercise claim in the statutory context. ${ }^{120}$ The individual plaintiff who asserts her free exercise claim against a large bureaucracy capable of justifying almost any action in terms of sweeping governmental interests runs the risk of appearing to be a troublemaker. ${ }^{121}$ In the shunning context, however, these roles are reversed; the disgruntled former member with dubious-sounding claims of intangible emotional harm confronts a unified church bureaucracy wielding the twin-edged sword of scriptural mandate and constitutional protection. In reality, shunning cases almost always involve good-faith disputes over religious doctrine. It is the difference of opinion on religious issues that compels the former member to leave the church or the church to excommunicate her. ${ }^{122}$ Both parties to the dispute invariably act according to the dictates of their respective views of religion.

If a court recognizes a cause of action for the former member, it burdens the free exercise of the group's faith. When families are involved however, or economic interests are at stake, a blanket refusal to recognize a cause of action for the former member goes too far the other way. The former member is effectively foreclosed from changing her beliefs or taking issue with church authorities, while, under Paul, the church is free to fashion a suitable "sanction" retroactively, after the

protection), and $P$ aul, (both the church and the individual changed their positions on issues of conscience, but only the church's free exercise rights were protected).

118 See Paul, 819 F.2d at 883.

119 See id. at 876.

120 See, e.g., United States v. Lee, 455 U.S. 252 (1982) (rejecting an Old Order Amish challenge to social security taxes).

${ }^{121}$ See id. at 258-60. The Court in Lee rejected Lee's claim to a religious exemption from social security withholding requirements, reasoning that the government's interest in the nationwide administration of the social security system "requires that some religious practices yield to the common good." Id. at 259.

122 See, e.g., Paul, 819 F.2d at 876 (plaintiff withdrew from church because she disputed the disfellowshipping of her parents and was prohibited from discussing this feeling with other members); Carrieri, 69 Wash. 2d at 539, 419 P.2d at 134 (action for alienation of affections after events arising out of appellant's determination that he "'couldn't quite agree with [the pastor's] style of preaching" "); see also R. BEAR, supra note 5, at 36-37 (author's excommunication and shunning were a result of pointing out that "the church wasn't as it professed to be"). 
member has left, in order to discourage errant behavior. ${ }^{123}$

Paul's weakness lay in the court's wooden application of the Sherbert analytical framework, which was designed to protect an individual's right to free exercise in the face of oppressive government regulation. ${ }^{124}$ In the shunning context, however, the alignment of the parties is reversed: the individual complains of oppressive church practices. Faced with competing rights to free exercise, the court must play the role of the "state" by choosing either to recognize or dismiss a free exercise defense. ${ }^{125}$

\section{Economic Damage}

Shunning can also cause tangible economic harm. In Lide v. Miller, ${ }^{128}$ a dentist brought an action against church elders for tortious interference with business relations. The church elders had read a statement alleging instances of Lide's misconduct to their congregation. The apparent result of this proclamation was harm to Lide's reputation and dental practice. ${ }^{127}$

The Texas Court of Civil Appeals stated that it had "no jurisdiction over and no concern with [] purely ecclesiastical questions and controversies," but that it did "have jurisdiction as to civil, contract and property rights even though such rights are involved in, or arise from, a church controversy." 128 The court, citing Bear, reversed the trial court's grant of summary judgment in favor of the church elders and remanded the case for trial upon the merits. ${ }^{129}$

Lide's significance is that it compels members of a religious group to exercise the same standard of care as an ordinary person when making statements that are likely affect a former member's standing in the community. This places former church members on an equal legal footing with those who remain in the group.

Similarly, Bear involved a claim for harm to the plaintiff's business in addition to his claim for emotional damages. ${ }^{130}$ Not only was Bear losing business, but he also found himself unable to hire workers,

123 See supra note 45.

124 See supra notes $30-37$ and accompanying text. 137.

125 See Paul, 819 F.2d at 879-80; Carrieri, 69 Wash. 2d at 544-45, 419 P.2d at

128 573 S.W.2d 614 (Tex. Civ. App. 1978).

127 See id.

128 Id. at 615 (citing Serbian E. Orthodox Diocese v. Milivojevich, 426 U.S. 696 (1976)).

129 See id. at 616.

130 See Bear, $462 \mathrm{~Pa}$. at 333, 341 A.2d at 106; supra notes 71-72 and accompanying text. 
obtain loans, or market his produce. ${ }^{131}$ The Bear court identified tortious interference with a business relationship as one possible area of " "paramount state concern."

Bear raises challenging questions of the extent to which "lifestyle" is bound up with religious beliefs. Is a church "exercising" its religion when it directs its members not to grant credit to or enter into the employ of a former member? What if the church asserts publicly, as apparently was the case in Bear, that the former member was dishonest? ${ }^{\text {1s3 }}$

These questions also involve difficult issues of public policy. ${ }^{134}$ The Mennonite context is perhaps the easiest in which to address such issues because of the intimate relationship between religious belief and the community way of life. ${ }^{135}$ The more a given group's beliefs are in harmony with its members' way of life and the longer their practices have been established, the stronger will be their claims to religious motivation for economic sanctions. ${ }^{136}$ It is the tightly knit group with a distinctive way of life that is most likely to engage in shunning practices in order to ensure uniformity within the group. ${ }^{137}$

Although neither court fully considered the implications of its decision in favor of the shunning victim, both the Bear and Lide courts reached the correct result on their respective facts. ${ }^{138}$ It is extremely difficult to ascertain on a demurrer or a summary judgment motion the veracity of a given communication or its intended effect. It may be appropriate in some contexts to examine the history of economic sanctions against former members. Greater deference should be accorded a group that has practiced shunning as a central tenet of its faith over an extended period of time than is given, for example, sanctions enunciated extemporaneously from a pulpit. Otherwise, religious groups would be free to adopt ad hoc sanctions without regard to the circumstances of

131 See Bear, $462 \mathrm{~Pa}$. at 333, 341 A.2d at 106.

132 Id. at 334,341 A.2d at 107.

133 See R. BEAR, supra note 5 , at 41.

134 See, e.g., Bob Jones Univ. v. United States, 461 U.S. 574 (1983) (rejecting the free exercise claim of a sectarian university that was denied tax exempt status because its religiously-inspired, racially-discriminatory admissions practices violated public policy).

135 $C f$. Wisconsin v. Yoder, 406 U.S. 205, 216 (1972) (noting the intimate connection between Amish belief and lifestyle).

${ }^{138}$ Cf. id. at 219 (noting that 300 years of consistent practice of the Amish religion and strong evidence of a sustained faith regulating its members' way of life support the claim that a state requirement of compulsory education until age 16 would "gravely endanger if not destroy" the free exercise of Amish beliefs).

137 See B. RAven \& J. RuBIN, supra note 1, at 319.

138 Cf. Lee, 455 U.S. at 257-58 (permitting the government to impose a limitation on free exercise if essential to achieve an overriding public policy interest). 
each case and later invoke the protection of the free exercise clause. Even when a given custom of economic sanctions has been in effect for a long time and occupies a central position in the group's doctrine, however, the court should still consider the free exercise interests of the victim of the shunning before reaching a decision.

\section{Child Custody}

A standard different from other cases involving shunning is required in child custody cases. First, neither party to the dispute claims to have been injured by the shunning practice; rather, one party is likely to claim that the child will be emotionally harmed if she is raised in an environment in which she is taught to reject that parent. Because the parents cannot agree on a custody decision, the court is called upon to substitute its judgment for that of the parents in deciding what is best for the child. Second, no church or church representative is a defendant for her role in compelling a third party to shun the plaintiff. Religious differences may have fueled the dispute that has culminated in a custody battle, but the group advocating the shunning is not being called upon to pay directly for the results of its religious belief; rather, the spouse applying the practice of shunning serves as a proxy for the church. The outcome of the child custody dispute therefore can be said to impose only an indirect burden on the group's religious practice; the group can continue its shunning practices, which may be directed toward the child if the child chooses not to follow the path of the parent remaining in the group.

If a child resides with the parent who continues to be affiliated with the religious group, she may be subjected to a steady barrage of ill-will directed towards the other parent ${ }^{139}$ and will be taught to avoid contact with that parent as much as possible. ${ }^{140}$ This state of affairs

139 Cf. Johnson v. Johnson, 564 P.2d 71, 73, 75-76 (Alaska 1977) (disfellowshipped church member claiming that he would receive "little, if any, access to his children by virtue of his disfellowshipped status"); Bear, $462 \mathrm{~Pa}$. at $333,341 \mathrm{~A} .2 \mathrm{~d}$ at 106 (1975) (children would not speak to father, an excommunicated church member).

A parent's intentions in isolating her children from a shunned spouse are not necessarily malicious. See Johnson, 564 P.2d at 73 (father introduced testimony indicating that his wife would try to keep him apart from his children because "a disfellowshipped member of the Jehovah's Witnesses is believed to be under, or in danger of coming under, satanic control"); cf. Linderman v. Linderman, 364 N.W.2d 872, 874 (Minn. Gt. App. 1985) (children expressed their desire to live with father, rather than shunned mother, at least in part because their ongoing church involvement was important to them).

140 See Quiner v. Quiner, 59 Cal. Rptr. 503, 505-06 (Ct. App. 1967) (mother testified at trial that if she received custody of young child, she would encourage him to separate from his father on religious grounds); Bear, $462 \mathrm{~Pa}$. at $332-33,341 \mathrm{~A} .2 \mathrm{~d}$ at 
does not comport with normal conceptions of a child's best interests. ${ }^{141}$ If courts, however, consider one parent's belief in shunning in granting custody to the other parent, they may be imposing a substantial burden on the shunning parent's free exercise rights. ${ }^{142}$ Given these sensitive issues, the parent's religion must be considered in a custody case only if the child's psychological well-being is potentially in danger.

Quiner v. Quiner ${ }^{143}$ is an example of a case in which the court did not take the parents' religion into account in determining the child's best interests. In Quiner, the mother belonged to a religious sect called the "Plymouth Brethren," or "Exclusive Brethren." This sect believed in what it termed the "Doctrine of Separation," which required members of the sect to avoid contact with nonmembers as much as possible. $^{144}$ The father had fallen away from the group and religious differences eventually led to divorce and a dispute over child custody. ${ }^{145}$ At trial, the mother was questioned about the role that the Doctrine of Separation would play in her five year old son's upbringing: " $\mathrm{Q}^{* * *}$. If your son joined the religious group according to the beliefs of your religion, he could not associate with his father; is that correct? In other words, he would have to practice the principle of separation from his father; is that correct? A*** Yes, he would."146 The trial court decided that this type of arrangement would not be in the best interests of the child and awarded custody to the father. ${ }^{147}$ The California Court of

106 (shunning requires a total boycott of the disfellowshipped member by other church members, including that member's children).

${ }^{141}$ The child's best interests is the standard applied in most adoption, guardianship, and custody proceedings. See generally L. PFeffer, Church, State and FreeDOM 703-04, 708, 711 (rev. ed. 1967) (noting various components of a child's best interests including health, temporal welfare, and happiness, and the effect of religious considerations on these interests); Note, Religion as a Factor in Adoption, Guardianship and Custody, 54 Colvm. I. Rev. 376, 393-94 (1954) (advocating the inclusion of the parents' religious affiliations as one consideration in decisions involving the child's best interests in adoption proceedings).

142 See, e.g., Johnson, 564 P.2d at 76 (holding that refusal to award custody to the mother could not be based upon her stated intention to raise children as Jehovah's Witnesses). But of. Morris v. Morris, 271 Pa. Super. 19, 34-35, 412 A.2d 139, 146-47 (1979) (holding that child's psychological well-being was a more compelling interest than parent's free exercise right and conditioning father's visitation rights upon agreement not to involve daughter in religious solicitation).

14359 Cal. Rptr. 503 (Ct. App. 1967).

14 See id. at 504, 508.

145 See id. at 506-08.

148 Id. at 505.

147 See id. at 504. The court operated under the state law presumption that, "all things being equal, the custody of a child of tender years should go to the mother." Id. at 517. In this case, however, the trial court not only granted custody to the father, but it conditioned the mother's visitation rights on an injunction prohibiting her from exposing the child to any doctrines or beliefs of the "Exclusive Brethren." See id. at 504. 
Appeals reversed, stating:

If a court has the right to weigh the religious beliefs or lack of them of one parent against those of the other, for the purpose of making the precise conclusion as to which one is for the best interests of a child, we open a Pandora's box which can never be closed. . . . [T]he First Amendment in conjunction with the Fourteenth solves the problem; it legally prohibits such religious evaluations. ${ }^{148}$

Custody was awarded to the mother, who stated that she would obey, albeit reluctantly, a court order giving the father visitation rights. ${ }^{140}$

The appeals court in Quiner apparently felt that the best way to deal with the religion problem was to ignore it. The mother's interest in free exercise therefore outweighed the child's best interests, or, put another way, the religious beliefs of the parents were irrelevant to the child's best interests, whatever the impact of those beliefs on the child's upbringing.

In Johnson $v$. Johnson, ${ }^{150}$ the court was presented with facts like those in Quiner, and it also chose not to consider the parents' religion in its custody decision. In Johnson, both father and mother were Jehovah's Witnesses. The father was disfellowshipped for willfully smoking cigarettes $^{\mathbf{1 5 1}}$ and was subsequently shunned. This rift placed a strain on the marital relationship and eventually led to divorce. ${ }^{152}$ The trial court granted custody of the children to the wife based on the "tender years" doctrine; $;^{153}$ the husband appealed, arguing that "he [would] be allowed little, if any, access to his children by virtue of his disfellowshipped status."154 The Supreme Court of Alaska remanded the case because the trial court had incorrectly based its custody decision upon the tender years doctrine, and it directed the lower court to reconsider the custody decision using the criteria put forth in its decision without reference to the mother's religious beliefs. ${ }^{155}$ "[G]ertainly, we cannot use Linda's continued membership in the Jehovah's Witnesses as a basis for directing the trial court to award the children to Rudy. To do so would be violative of her right to freedom of religion under the First

148 Id. at 517.

149 See id. at 505, 517.

150564 P.2d 71 (Alaska 1977).

151 See id. at 72.

182 See id. at 72-73.

$18 s$ See id. at 73.

104 Id. at $75-76$.

155 See id. at 75, 77. The Johnson court emphasized that custody decisions should be based upon serving the child's "best interests." See id. at 74-75. 
Amendment."158 Thus, Johnson was in agreement with Quiner. In fact, it went one step further by asserting that the best interests of children did not include assimilation into the dominant culture. ${ }^{187}$ This assertion countered the husband's assertion that, by granting custody to the mother, the court was not only denying the children free access to him, but also restricting the children's access to the "expansive atmosphere" of mainstream society. ${ }^{168}$

The court in Morris $v$. Morris, ${ }^{168}$ took the opposite approach by accounting for the likely effect of the parent's religious practices on the child. Morris did not involve shunning, but its rationale is instructive. The father, who was a Jehovah's Witness, sought to overturn a lower court custody decree conditioning his visitation rights upon his agreement not to take his five-year-old daughter on any door-to-door religious solicitations. ${ }^{160}$ The father claimed that this condition violated his free exercise rights. Expert testimony had been offered at trial indicating that door-to-door solicitation might be psychologically harmful to so young a child and that the inconsistency between the father's and the mother's religious teachings would likely result in the child's disregarding all religion. ${ }^{161}$ The father argued that this testimony was unproven and that, in any case, the expert had only indicated that religious solicitation might prove harmful to the child. ${ }^{162}$ The court responded by stating that "we cannot accept an argument that the absence of present harm constricts the court's power to act. Were this the case, we would have to allow the psychological harm to ... [the child] to progress to a mentally crippling point before action could be taken."16s Thus, the Morris court not only placed a burden upon the parent's free exercise in order to accommodate the best interests of the child, but it also did not require the prevailing party to demonstrate present harm to the child; the court instead based its decision on a prediction of harmful future effects. ${ }^{164}$

There are arguments to be made for and against each approach in the child custody context. By refusing to consider the likely effects of a

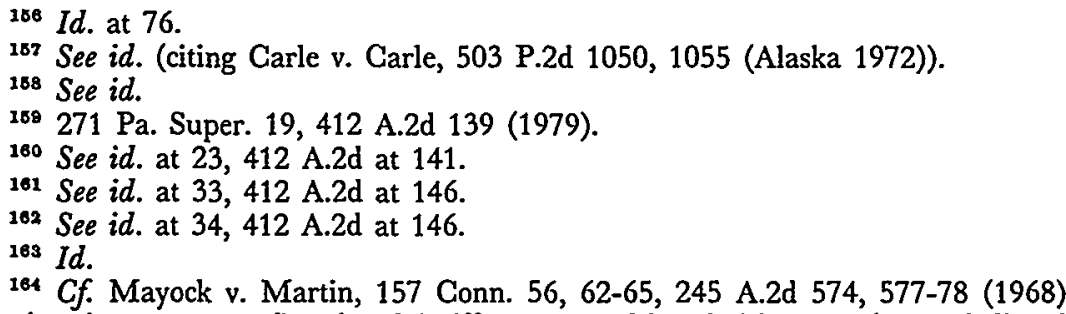

164 Cf. Mayock v. Martin, 157 Conn. 56, 62-65, 245 A.2d 574, 577-78 (1968) (allowing the state to confine the plaintiff to a mental hospital because doctors believed his religious beliefs might induce him to cut off his foot), cert. denied, 393 U.S. 1111 (1969). 
parent's religious practices in a custody decision, courts avoid the temptation to inject their own morality-or that of the "dominant culture"-as a hypothetical "best" morality for the child. ${ }^{185}$ On the other hand, other cases illustrate that ignoring the likely effects of the parents' religious practices could sacrifice the best interests of the child. ${ }^{168}$

Perhaps the most reasonable line of analysis to follow in child custody cases is slightly different from the one this Comment advocated earlier in the context of alienation of affections and tortious interference with contractual relationships. ${ }^{187}$ First, the court would have to establish that the best interests of the child are a matter of paramount state concern. ${ }^{168}$ The court would then make the custody decision on a relig-

165 By abstaining from the religious issue, courts avoid results such as the one reached in Shelley v. Westbrooke, Jac. 266, 37 Eng. Rep. 850 (1817), in which the English poet Percy Bysshe Shelley was denied custody of his two children after the death of his wife because he was an avowed atheist:

This is a case in which ... the father's principles cannot be misunderstood, in which his conduct, which I cannot but consider as highly immoral, has been established ... as the effect of those principles .... .

I cannot, therefore, think that I should be justified in delivering over these children [to the father] ...."

Id. at 851 .

Shelley had published works on atheism. See Shelley \& Hogg, The Necessity of Atheism, in ShelleY's Prose 37 (D.L. Clark ed. 1954). The court referred to publication of atheistic works as Shelley's "immoral conduct." See Shelley, Jac. 266, 37 Eng. Rep. at 850-51.

Atheism and agnosticism have been recurrent themes in child custody and adoption proceedings in the United States. See, e.g., Dickens v. Ernesto, 30 N.Y.2d 61, 281 N.E.2d 153, 330 N.Y.S.2d 346, appeal denied for lack of a federal question, 407 U.S. 917 (1972). In Dickens, a couple's application to become adoptive parents was refused because they had no religious affiliation. The state statute then governing the placement of adopted children directed that they should be placed so as to give effect to the religious wishes of the natural parents. The court rejected the couple's free exercise claim, reasoning that

[u]nder these circumstances, religious conformity provisions which serve a valid secular purpose may not be said to discriminate against or penalize the petitioners because they do not have a religious affiliation, nor are they thereby placed under an obligation to assume a religious faith in order to be able to adopt a child.

Id. at 68, 281 N.E.2d at 157, 330 N.Y.S.2d at 350; see also In re Adoption of "E," 59 N.J. 36, 40, 51, 279 A.2d 785, 787, 793 (1971) (reversing a lower court judgment that "plaintiffs' lack of belief in a Supreme Being rendered them unfit to be adoptive parents" and holding that the lower courts' treatment of the plaintiffs' atheism as controlling in the adoption proceedings had violated their free exercise rights).

${ }^{168}$ See, e.g., Morris, $271 \mathrm{~Pa}$. Super. at 34-35, 412 A.2d at 146-47 (attempting to prevent psychological harm to a child by taking into account the father's religious practices and therefore conditioning his visitation rights on his agreement not to involve the child in door-to-door solicitation).

167 See supra notes 61-138 and accompanying text.

168 See L. PFEFFer, supra note 141, at 708 ("[W] hen a court is called upon to fix the custody of a child, as where the parents separate, the universal rule is that it should 
ion-blind basis. This decision would stand unless one party, or a courtappointed expert, satisfied her burden of proving that a substantial likelihood exists that the child's best interests would be disserved as the proximate result of the other parent's religious practices. ${ }^{169}$ In other words, a parent's religion would be considered only if one of the parties claimed that the beliefs and practices of the other parent would jeopardize the child's physical or psychological well-being. If the party does not raise this issue or meet the burden, then the rationale for the court's holding should remain religion-blind. Religion would thus become one factor to be weighed in a custody decision aimed primarily at furthering the child's best interests.

The mechanics of this test can be illustrated by applying it to the facts of Quiner. In Quiner, the court was required to choose between awarding custody to the mother, who practiced the principle of separation, and the father, who did not. The trial court had awarded custody to the father and had conditioned the mother's visitation rights upon her agreement to refrain from indoctrinating the child in her religion. ${ }^{170}$ The trial court also found, however, that both parents were of sound character and that both were devoted to the child. ${ }^{171}$

In circumstances in which both parents are of sound character and devoted to the child, custody should be granted to the parent who would be awarded custody if religion were not a factor. If this religionblind test had been applied in Quiner, the mother would have been awarded custody of the young child, because under California law, "all things being equal, the custody of a child of tender years should go to the mother."172 This decision would be final unless the father could produce evidence that the child's best interests would be frustrated as the proximate result of the mother's religion. Given that (1) the mother agreed to abide by a court visitation order; (2) the mother promised to teach the child to love and respect his father; ${ }^{173}$ and (3) the court found

be guided exclusively by what it deems to be the child's best interests."); see also Johnson, 564 P.2d at 74 (noting Alaska law requiring courts to consider the best interests of the child in custody cases); Quiner, 59 Cal. Rptr. at 509 ("The law of this state makes it abundantly clear that the best interests of the child is the polestar of decision in custody cases. We know of no state in which it is different."); Morris, $271 \mathrm{~Pa}$. Super. at $24,412 \mathrm{~A} .2 \mathrm{~d}$ at 141 ("It is well established that in all cases involving the custody of a child, the paramount consideration is the best interests and welfare of the child. . . [This] embraces the child's physical, intellectual, moral, and spiritual well-being.").

${ }_{160} \mathrm{Cf}$. Note, supra note 141, at 393 ("Before transferring a child from one custodian to another because of the religious component, thought should certainly be devoted to the psychological or economic harm which may result to the youngster.").

170 See Quiner, 59 Cal. Rptr. at 504.

171 See id.

172 Id. at 517.

17 See id. at 505. 
the psychological evidence adduced at trial inadequate to justify the conclusion that the child's well-being would be impaired by exposure to the "Doctrine of Separation," the facts of Quiner would warrant granting custody to the mother.

The above standard is the proper one to apply in shunning cases involving child custody. In the child custody context, the court's decision is not immutable. ${ }^{174}$ Therefore, if evidence came to light that a child was being harmed by the religious practices of one parent, the court could order a new arrangement. This standard would favor religion-neutral custody decisions absent compelling evidence that the child would be harmed.

\section{CONCLUSION}

This Comment has adopted an approach to religious shunning that has never been used in a court of law. The approach advocated by this Comment, however, is very simple: when religious groups shun their members, more is at stake than the religious freedom of the group. Each member of the group has free exercise rights at least as compelling as the group that shuns them.

The test of Sherbert $v$. Verner ${ }^{175}$ should be applied with this guiding principle in mind. When courts ignore the free exercise rights of individuals and look only at the religious claims of groups, they elevate the group's religion over the individual's religion. This is a dangerous path to follow. It gives religious groups virtually unfettered coercive power over their members and former members and blocks dissent and doctrinal development.

Finally, this Comment has argued for a different test when shunning behavior becomes an issue in child custody disputes. This standard would ignore religious considerations unless there is a substantial danger of harm to the child.

124 See, e.g., Lerner v. Superior Court, 38 Cal. 2d 676, 682, 242 P.2d 321, 324 (1952) ("Custody decrees are universally subject to modification upon a showing of facts that require a change in the order to protect . . . the welfare of the child."); Quiner, 59 Cal. Rptr. at 518 (stating that the father could have the custody decision changed if it turned out that the child was being harmed by the mother's religion).

170374 U.S. 398 (1963). 